\title{
ASPECTS OF THE ENVIRONMENT AND NATURE PROTECTION IN THE GERMAN-POLISH BORDER REGION OF THE ODER LAGOON
}

\author{
Thora M. Herrmann, \\ Universite de Paris-Sorbonne (Paris IV, France
}

Key-words

German-polish border region of Odra estuary; eclogical problems; environmental protection and nature protection: Protection of the Baltic Sea, waterquality, management of groundwater and waste water : hilateral cooperation

\begin{abstract}
The environmental problems of today have more and more border-crossing character. In the present paper the ecological problems of the german-polish border region of the Odra estuary, which form a border-crossing ecological sensible unit, were studied for special parts of environmental protection, nature protection and water management regarding the quality of internal and external coastel waters, international conventions for protection of the Baltic Sea, cooperation in the field of protection and management of groundwater and waste water.

A critical summarized evaluation based on the analysis was established which helps identifing the defizits and possibilities for progess of the bilateral cooperation and which indicate precise focal points for border-crossing fields of actions in the region of Odraestuary, to ensure a sustainable and continuing developpement of this region.
\end{abstract}

\section{Introduction}

The ecological problems most crucial today present an increasingly transborder character, even a world dimension. The interetatic co-operation thus became a requirement, if one wants to bring effective solutions to these problems. The example of the germano-Polish area transfrontaliere of the estuary of Oder located at the Eastern border of the European Union, on the Baltic and which include the lagoon of Szczecin and the areas which extend on approx. 50 $\mathrm{km}$ east and west from the germano-polish common border, was selected to draw up an inventory of fixtures of the environmental protection and nature and to expose certain aspects of them.

The study area shows the same natural characteristics on the two sides of the border, namely the estuary and its circumference as well as interior and external coastal waters of the Baltic. Consequently, questions of environmental protection which relate to the quality of water, in particular coastel water, questions related to the production of drinking waters and the management of waste water are in the center of the transborder cooperation. They will be analyzed in the presente paper. 


\section{Transborder cooperation in the field of analysis of the water quality of the Coastal} $\underline{\text { Waters }}$

\section{Interior coastal water - the lagoon of Szczecin ( Zalew Szczecinski, Stettiner Haff}

The lagoon of Szczecin is characterized by a fresh water contribution coming from Oder $(58,5$ $\%$ of the total fresh water contribution), from rivers $(17 \%)$ and lakes $(25,5 \%)$, by a weak exchange out of salt water with the Baltic sea, by weak dynamics of the rivers and by relatively stable hydrographic conditions. These unfavourable hydromorphologic and hydrological conditions cause eutrophication. Because of important pollution due to toxic substances and nutritive substances (categories 4 to 5), the lagoon of Szczecin among interior coastal water counts the most threatened of the basin of the Baltic sea (HELCOM 1996) and quality analyzes of transborder water acquires a great importance.

Since 1968, the quality of water of the lagoon of Szczecin is controlled, in accordance with the bilateral Agreement concluded on March 13, 1965 between GDR and the popular Republic from Poland. These controls are carried out between April and November, in 12 stations given, by the agencies of German and Polish water (Fig. 1). Each year in September, the German-Polish Commission of frontier water makes taking away of water which proceed and which are analyzed jointly. The Polish and German partners draw up each year in turn the report on the quality and the state of water (UM 1992, PIOS 1993, STAUN 1994, PIOS 1995, STAUN 1996, PIOS 1997, STAUN 1998, PIOS 1999).

These reports were evaluated to study the evolution of the quality of water following the political upheavals. In same time, the impact of raw of Oder (July 21 at August 20, 1997) on the quality of water is measured, by melting on the existing data. An exact comparative analysis proves to be delicate, since the rates were indexed during several years at various measuring sites and different days.

More particularly in this paper the parameters "salinity, nitrates, ammonium, orthophosphates, metals heavy, chlorophyl A and oxygen", have been studied and evaluated separately from the measurements taken since 1991 to the three measuring sites: E - Estuary of Oder to the lagoon of Szczecin, close to Trzebiez and to Szczecin, B - the coast of the lagoon of Szczecin (Haffküste) with Usedom; Drainage duct towards the Large Lagoon (Wielki Zalew) of Szczecin; P - towards the Small Lagoon (Kleines Haff) of Szczecin (Fig. 1).

The rates of salinity (Tab 1) vary from a measuring site to the other, as one had to expect it for the 3 stations. On average, the lowest rates were detected at the station $\mathrm{E}$ and the highest rates at the station $\mathrm{B}$. These variations are also explained by the various sites of the stations, since the rate of salinity of the lagoon of Szczecin depends on the one hand on the surge of Oder $\left(550 \mathrm{~m}^{3} / \mathrm{s}\right)$ and on the other hand backward flow of the Baltic. An interesting fact is the evolution of salinity in August 1997 and July, during the rising of Oder: 5 billion fresh water $\mathrm{m}^{3}$ additional ran in the lagoon of Szczecin (on August 5, 1997, surge of Oder: $3000 \mathrm{~m}^{3} / \mathrm{s}$ ). This caused a water softening of the lagoon of Szczecin and that led to a reduction in salinity during August and July 1997 (Fig 2). In the small lagoon, at the station P a fall of the concentrations from 1,1 to 0,2 per thousand on average was detected at the height of the rising end juillet/beginning August until September. Once the returned normal flow, the salt concentration increased again, even if it reached the multiannual averages only at the end of the year. The rates of salinity were maintained on a rather low level in 1998 also, following an increased flow of Oder, on average, and of a weak influence of the Baltic sea. 


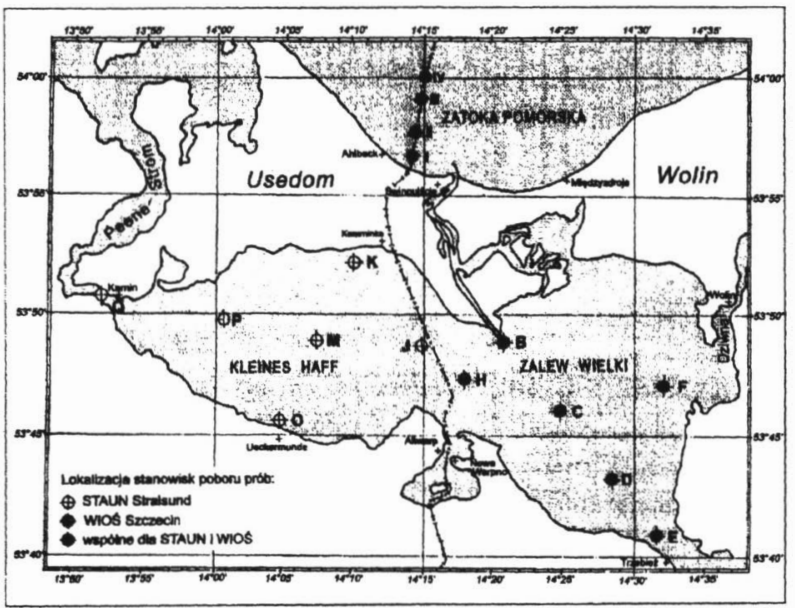

Fig. 1

Measuring sites intended for the sampling in the lagoon of Szczecin and Pomeranian Bay (Source: PIOS 1999)

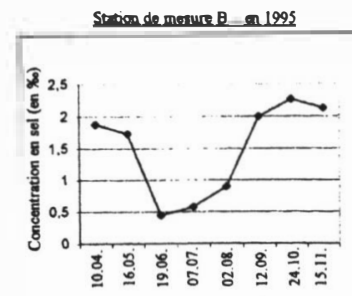

Jour de prélèvement d'échantillons en 1995

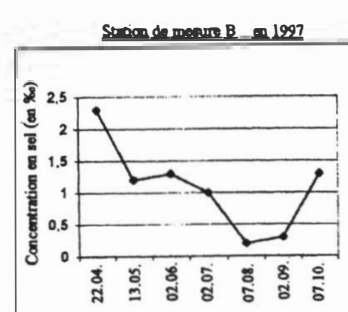

Jour de priblèvement d'óchantillions en 1997

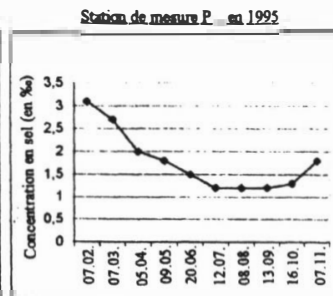

Jour de prélioven d'échmatilloas wo 1995

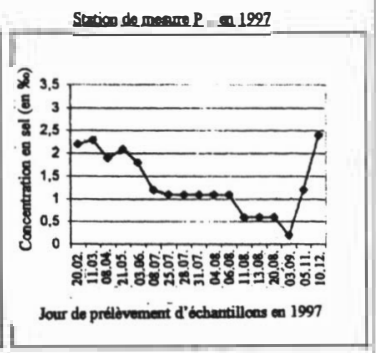

Fig. 2

Salt concentration (in \%o) in 1995 and 1997 for the $P$ and measuring sites $B$ in the lagoon of Szczecin (source: PIOS 1999) 
The large lagoon (Wielki Zalew) and the small lagoon (Kleines Haff) show differences on the level of the content nitrates.

The contents nitrates are generally higher in the large lagoon of Szczecin. The highest rates are detected at the station E, which is characteristic of the influence of strongly polluted Oder. The Commission of frontier water which evaluates since 1975 the rates at the station E notes a fall of the maximum rate. In 1976, the maximum concentrations which had been detected bordered $185 \mu \mathrm{mol} / \mathrm{l}(=2.52 \mathrm{mg} / \mathrm{l})$. Since 1990 , the rates rise between approximately 1,0 and $1,9 \mathrm{mg} / \mathrm{l}$ (STAUN 1998). The generalized fall is explained by the reorganizations of agriculture and industry after 1990 .

The variations of the nitrate rates recorded between 1990 and 1995 are due to weather factors (rainy winter cause a rise of the contents).

The rising of Oder caused an increase out of arrow of the nitrate concentrations at certain places of the two water levels. In the German part of the lagoon of Szczecin, the nitrate concentrations reached $0,3 \mathrm{Mg} \mathrm{N} / \mathrm{l}$ for a short period (11.08.1997), because of the contributions in nutritive substances with the wave of believed of Oder; this increase was followed of a return to the usual rates bordering the 0 and $0,02 \mathrm{Mg} \mathrm{N} / \mathrm{l}$ (BLUM 1997), because of biological changes. In 1998, the increase in concentrations in nutritive substances was due to an increased influence of Oder.

The ammonium which is a relevant indicator of pollution anthropogenes had reached its highest rate at the station E, during every year of catch of measurements. The role of Oder, the largest conveyor of nutritive substances, is thus shown. The evaluation of the ammonium rates taken in 1997 to the three stations $\mathrm{P}, \mathrm{Biand} \mathrm{E}$ indicates a reduction in the concentrations during the rising of the lagoon of Szczecin in 1997, and in particular in the small lagoon (table 2). The averages did not rise any more but between $0,05 \mathrm{mg} / \mathrm{l}$ and $0,1 \mathrm{mg} / \mathrm{l}$. At the station $\mathrm{P}$, the rates were in deça detectable limits to carry out analyses. From September, the concentrations reached the usual rates again. The mixture of water of Oder with water of the lagoon thus caused a dilution (STAUN 1998).

Tab 2

Ammonium concentration (in $\mu \mathrm{mol} / \mathrm{l}$ ) in 1997 for the $E$, measuring sites $B$ and $P$ (from July to September) in the lagoon of Szczecin (Source of the data: STAUN 1998)

\begin{tabular}{|l|l|l|l|}
\hline & \multicolumn{2}{c}{ Measuring site B } & 12091997 \\
\hline $\begin{array}{l}\text { Date } \\
\mu \mathrm{mmol} / \mathrm{l} \text { ) }\end{array}$ & 02071997 & 02.08 .1997 & 12.09 \\
\hline
\end{tabular}

\begin{tabular}{|c|c|c|c|}
\hline \multicolumn{4}{|c|}{ Measuring site E } \\
\hline Date & 02.07 .1997 & 02.08 .1997 & 12.09 .1997 \\
\hline $\begin{array}{l}\text { Ammonium concentration (in } \\
\mathrm{mol} / \mathrm{l}\end{array}$ & 15,01 & 7,14 & 18,20 \\
\hline
\end{tabular}

\begin{tabular}{|c|c|c|c|c|c|c|c|c|c|c|}
\hline \multicolumn{11}{|c|}{ Measuring site $\mathbf{P}$} \\
\hline Date & $\begin{array}{l}08.07 . \\
1997\end{array}$ & $\begin{array}{l}25.07 . \\
1997\end{array}$ & $\begin{array}{l}28.07 . \\
1997\end{array}$ & $\begin{array}{l}31.07 . \\
1997\end{array}$ & $\begin{array}{l}04.08 . \\
1997\end{array}$ & $\begin{array}{l}06.08 . \\
1997\end{array}$ & $\begin{array}{l}11.08 . \\
1997\end{array}$ & $\begin{array}{l}13.08 . \\
1997\end{array}$ & $\begin{array}{l}20.08 . \\
1997\end{array}$ & $\begin{array}{l}03.09 \\
1997\end{array}$ \\
\hline $\begin{array}{l}\text { Ammonium } \\
\text { concentration } \\
\text { (in } \mu \mathrm{mol} / \mathrm{l} \text { ) }\end{array}$ & 6,84 & 1,04 & $<0,70$ & $<0,70$ & $<0,70$ & $<0,70$ & $<0,70$ & $<0.70$ & $<0,70$ & 0,99 \\
\hline
\end{tabular}


One observes since 1990 a fall sensitive of the content orthophosphates to each of the three stations (tab 1). At the time of believed of Oder, the orthophosphate concentrations slightly decreased. The maximum rates from 6 to $8 \mu \mathrm{mol} / \mathrm{l}$ taken in the small lagoon are definitely lower than the multiannual averages which oscillate between 18 and $24 \mu \mathrm{mol} / \mathrm{l}$ (STAUN 1998). The influence of believed of Oder (28.07.97 - 20.08.1997) appears here also by a dilution. Since August 20, 1997, the orthophosphate rates went up at the usual rates.

In addition to nutritive substances, heavy metals constitute one of principal pollution of the lagoon of Szczecin. Since 1992. heavy metal pollution is measured at certain stations (B, M, E) in water close to surface. Tab 3 relating to the stations B, E and M (aucunes measurements was not made at the station P) gives an outline of the evolution. It appears that the large lagoon is stronger polluted than the small lagoon. Perhaps it is necessary to seek of it the reason mainly in the flow of Oder $(85 \%)$, because of the junction with Swina and Dzwina and thus with the large lagoon. That also causes a North-South significant variation, because of influence of Oder like principal source of pollution.

The heavy metal concentrations did not evolve in an identical way in the two parts of the lagoon of Szczecin. With regard to lead, mercury, zinc, copper and nickel, the rates detected in the large lagoon decreased between 1993 and 1997. The measurements analyzed in 1997 have the lowest rates since the beginning of the taking away in 1992, following the dilution caused by the rising of Oder, then the rates went up in 1998. An increase in the heavy metal concentrations was noted between 1993 and 1998 in the small lagoon. The rising of Oder generated the day of the wave of rising, July 28, 1997, an increase in the mercury and lead rates which are reflected particularly in the small lagoon. Lead the concentrations of about $3.28 \mu \mathrm{g} / \mathrm{l}$. highest since the beginning of the taking away in 1992, were recorded on July 28 , 1997 in the small lagoon (station M). the rising of Oder did not involve additional zinc and copper, nickel pollution.

The high percentage of nutritive substances proves the eutrophic character of the lagoon of Szczecin. The consequence is an increase in the primary production in algae which one can show trought the high percentage of chlorophyl A detected at the three stations.

The average oxygen rates are of $11 \mathrm{mg} / \mathrm{l}$ in the large lagoon and of $13,4 \mathrm{mg} / \mathrm{l}$ in the small lagoon (table 1). Strong organic pollution, the specific hydrological character of water and the climatic conditions lead, during the summer months, with a process of exhaustion of oxygen. Thus the weakest concentration oxygenates some was measured on June 12, 1991 at the station E; it rose with $7.7 \mathrm{mg} / \mathrm{l}$ on the surface of water and with $3,8 \mathrm{mg} / \mathrm{l}$ close to the bottom (from $2 \mathrm{mg} / \mathrm{l}$, the rates are toxic for fish). Similarly low rates were measured at other stations (station OG, 1992: $6.3 \mathrm{mg} / \mathrm{li}$ station E, 1996: $5,5 \mathrm{mg} / \mathrm{l}$; station D, 1996: $4,6 \mathrm{mg} / \mathrm{l}$ close to the bottom) (STAUN 1993, STAUN 1997). The low oxygen content leads locally to a mortality of fish, with all the negative consequences that that involves for the practice of the bathes on banks of the lagoon.

One notes using this short evaluation a positive evolution of the quality of water. This tendency towards best is regarded as one of the results of the bilateral co-operation which, for several years, has been carried out in an intensive way in the field of protection of water (Report from the 13 to April 15, 1999). The evaluation made during the rising of Oder in 1997 shows the particular part played hy the lagoon of Szczecin like spaces natural elimination of substances biologically degradables. The whole of the lagoon of Szczecin constitutes a buffer system vis-a-vis the Baltic. It thus exerts a considerable influence on the 
mass transfer of Pomeranian Bay. Within sight of this complexity, it proves to be imperative to intensify the transborder co-operation, since its impact exceeds the zone of the Baltic.

Tab 1 Annual averages of the parameters: salt, oxygen, nitrates, ammonium, orthophosphates and chlorophyl $A$ in the lagoon of Szczecin at the measuring sites B, E and P, of 1991 to 1998 (Source of the data: UM 1992, PIOS 1993, STAUN 1994, PIOS 1995, STAUN 1996, PIOS 1997, STAUN 1998, PIOS 1999)

\begin{tabular}{|l|l|l|l|l|l|l|l|l|}
\hline \multicolumn{7}{|c|}{ Measuring site B } \\
\hline Parameter & $\mathbf{1 9 9 1}$ & $\mathbf{1 9 9 2}$ & $\mathbf{1 9 9 3}$ & $\mathbf{1 9 9 4}$ & $\mathbf{1 9 9 5}$ & $\mathbf{1 9 9 6}$ & $\mathbf{1 9 9 7}$ & $\mathbf{1 9 9 8}$ \\
\hline Salt (\%o) & 3,20 & 1,64 & 2,26 & 1,80 & 1,49 & 1.29 & 1,10 & 1,75 \\
\hline $\begin{array}{l}\text { Oxygenate } \\
(\mathrm{mg} / \mathrm{I})\end{array}$ & $\mathrm{n} \cdot \mathrm{m}^{*}$ & $\mathbf{9}, 17$ & 10,36 & $\mathrm{n} \cdot \mathrm{m}$. & 10,8 & 13,5 & 13,3 & 10,8 \\
\hline Nitrates (mg/l) & 0,44 & 0,76 & 0,522 & 0,7 & 0,705 & 1,05 & 0,38 & 1,30 \\
\hline $\begin{array}{l}\text { Ammonium } \\
\text { (mg/l) }\end{array}$ & 0,052 & 0,05 & 0,025 & $\mathrm{n} . \mathrm{m}$. & 0,004 & 0,06 & 0,0029 & 0,03 \\
\hline $\begin{array}{l}\text { Orthophos- } \\
\text { phates (mg/l) }\end{array}$ & 0,11 & 0,02 & 0,08 & 0,05 & 0,09 & 0,046 & 0,055 & 0,06 \\
\hline $\begin{array}{l}\text { Chlorophyl A } \\
\left(\mathrm{mg} / \mathrm{m}^{3}\right)\end{array}$ & 64,5 & 71,89 & 31,37 & 46,0 & 51,00 & 52,0 & 61,030 & 48,7 \\
\hline
\end{tabular}

\begin{tabular}{|l|l|l|l|l|l|l|l|l|}
\hline \multicolumn{7}{|c|}{ Measuring site E } \\
\hline Parameter & $\mathbf{1 9 9 1}$ & $\mathbf{1 9 9 2}$ & $\mathbf{1 9 9 3}$ & $\mathbf{1 9 9 4}$ & $\mathbf{1 9 9 5}$ & $\mathbf{1 9 9 6}$ & $\mathbf{1 9 9 7}$ & $\mathbf{1 9 9 8}$ \\
\hline Salt (\%o) & 0,40 & 0,54 & 0,40 & 0,30 & 0,25 & 0,18 & 0,30 & 0,30 \\
\hline $\begin{array}{l}\text { Oxygenate } \\
\text { (mg/l) }\end{array}$ & n.m. & 8,61 & $\mathbf{8 , 0 2}$ & n.m. & 8,80 & 9,50 & 8,00 & 9,0 \\
\hline Nitrates (mg/l) & 1,27 & 1,01 & 1,423 & 1,30 & 1,484 & 1,9 & 1,12 & 1,16 \\
\hline $\begin{array}{l}\text { Ammonium } \\
\text { (mg/l) }\end{array}$ & 0,28 & 0,24 & 0,273 & n.m. & 0,217 & 0,23 & 0,095 & 0,24 \\
\hline $\begin{array}{l}\text { Orthophos- } \\
\text { phates (mg/l) }\end{array}$ & 0,20 & 0,08 & 0,033 & 0,04 & 0,088 & 0,09 & 0,0 & 0,02 \\
\hline $\begin{array}{l}\text { Chlorophyl A } \\
\left(\mathrm{mg} / \mathrm{m}^{3}\right)\end{array}$ & 64,5 & 47,8 & 28,90 & 66,0 & 63,4 & 53,0 & 48,7 & 48,7 \\
\hline
\end{tabular}

\begin{tabular}{|l|l|l|l|l|l|l|l|l|}
\hline \multicolumn{9}{|c|}{ Measuring site P } \\
\hline Parameter & $\mathbf{1 9 9 1}$ & $\mathbf{1 9 9 2}$ & $\mathbf{1 9 9 3}$ & $\mathbf{1 9 9 4}$ & $\mathbf{1 9 9 5}$ & $\mathbf{1 9 9 6}$ & $\mathbf{1 9 9 7}$ & $\mathbf{1 9 9 8}$ \\
\hline Salt (\%o) & 1,9 & 2,18 & 2,34 & 1,9 & 1,78 & 1,0 & 1,3 & 1,04 \\
\hline $\begin{array}{l}\text { Oxygenate } \\
(\mathrm{mg} / \mathrm{l})\end{array}$ & n.m. & 11,09 & 9,9 & n.m. & 11,2 & 11,2 & 12,4 & 10,7 \\
\hline Nitrates (mg/l) & 0,18 & 0,45 & n.m. & 0,7 & 0,609 & 0,45 & 0,47 & 0,52 \\
\hline $\begin{array}{l}\text { Ammonium } \\
\text { (mg/l) }\end{array}$ & 0,038 & 0,03 & n.m. & n.m. & 0,014 & 0,03 & 0,05 & 0,09 \\
\hline $\begin{array}{l}\text { Orthophos- } \\
\text { phates (mg/l) }\end{array}$ & 0,2 & 0,02 & n.m. & 0,05 & 0,058 & 0,063 & 0,09 & 0,04 \\
\hline $\begin{array}{l}\text { Chlorophyl A } \\
\left(\mathrm{mg} / \mathrm{m}^{3}\right)\end{array}$ & 62,5 & 57,32 & 58,2 & 54,0 & 43,6 & 66,8 & 58,5 & 37,7 \\
\hline
\end{tabular}

- n.m. $=$ non mésuré 
Tab 3

Annual averages of the heavy metal concentrations (in $\mu \mathrm{g} / \mathrm{l}$ ) for lead, copper, nickel, mercury and zinc in the lagoon of Szczecin at the measuring sites B, E and M, of 1993 to 1998 (Source of the data: STAUN 1994, PIOS 1995, STAUN 1996, PIOS 1997, STAUN 1998, PIOS 1999)

\begin{tabular}{|l|l|l|l|l|l|}
\hline \multicolumn{7}{|c|}{ Measuring site B } \\
\hline Metal heavy & $\mathbf{1 9 9 3}$ & $\mathbf{1 9 9 5}$ & $\mathbf{1 9 9 7}$ & $\mathbf{1 9 9 8}$ & $\begin{array}{l}\text { Directing rates indicated by } \\
\text { the HELCOM (แg/l) }\end{array}$ \\
\hline Lead $(\mathrm{ug} / \mathrm{l})$ & 2,0 & 1,86 & 0,002 & 2,0 & $0,05^{*}$ \\
\hline Copper $(\mu \mathrm{g} / \mathrm{l})$ & 4,7 & 2,41 & 0,003 & 3,0 & $0,05^{*}$ \\
\hline Nickel $(\mu \mathrm{g} / \mathrm{l})$ & n.m. & 2,06 & 0,003 & 2,0 & $0,7-0,8$ \\
\hline Mercury $(\mu \mathrm{g} / \mathrm{l})$ & n.m. & 0,057 & 0,000 & 1,0 & $0,003^{*}$ \\
\hline Zinc $(\mu \mathrm{g} / \mathrm{l})$ & 18,8 & 11,7 & 0,008 & 9,0 & $1-10$ \\
\hline
\end{tabular}

\begin{tabular}{|c|c|c|c|c|c|}
\hline \multicolumn{6}{|c|}{ Measuring site E } \\
\hline Metal heavy & 1993 & 1995 & 1997 & 1998 & $\begin{array}{l}\text { Directing rates indicated by } \\
\text { the HELCOM }(\mu \mathrm{g} / \mathrm{l})\end{array}$ \\
\hline Lead $(\mu \mathrm{g} / \mathrm{l})$ & 3,1 & 2,06 & 0,003 & 3,0 & $0,05^{*}$ \\
\hline Copper $(\mu \mathrm{g} / \mathrm{l})$ & 6,0 & 3,19 & 0,004 & 6,0 & $0,05^{*}$ \\
\hline Nickel $(\mu \mathrm{g} / \mathrm{l})$ & n.m. & 2,59 & 0,004 & 3,0 & $0,7-0,8$ \\
\hline Mercury $(\mu \mathrm{g} / \mathrm{l})$ & n.m. & 0,338 & 0,000 & 1,0 & $0,003^{*}$ \\
\hline Zinc $(\mu \mathrm{g} / \mathrm{l})$ & 31,3 & 18,9 & 0,015 & 15,0 & $1-10$ \\
\hline
\end{tabular}

\begin{tabular}{|c|c|c|c|c|c|}
\hline \multicolumn{6}{|c|}{ Measuring site $\mathrm{M}$} \\
\hline Metal heavy & 1993 & 1995 & 1997 & 1998 & $\begin{array}{l}\text { Directing rates indicated by } \\
\text { the HELCOM (ug/l) }\end{array}$ \\
\hline Lead $(\mu \mathrm{g} / \mathrm{l})$ & 0,76 & $0, \mathbb{0} 0$ & 1,06 & 1,48 & $0,05^{*}$ \\
\hline Copper $(\mu \mathrm{g} / \mathrm{l})$ & 0,2 & 0,96 & 1,65 & 1,74 & $0,05^{*}$ \\
\hline Nickel $(\mu \mathrm{g} / 1)$ & 0,5 & 0,5 & 1,24 & 1,52 & $0,7-0,8$ \\
\hline Mercury ( $\mathrm{gg} / \mathrm{l})$ & 0,1 & 0,042 & 0,06 & 0,048 & $0,003^{*}$ \\
\hline Zinc $(\mu \mathrm{g} / \mathrm{l})$ & 3,1 & 1,50 & 6,60 & 5,57 & $1-10$ \\
\hline
\end{tabular}

* The guideline figures apply to the coastal sections subjected to this influence, while all the other guideline figures relate to the central part of the Baltic

\section{External coastal water - the Pomeranian Bay (Zatoka Pomorska, Pommersche Bucht)}

The Pomeranian Bay forms, with its external coastal water, a part of the south of the Baltic; it is limited by the coastal lines of the islands Usedom and Wolin. Peenestrom, the arms of the estuary of Oder and the rivers Swina and Dzwina are thrown in Pomeranian Bay. Because of the important contributions in harmful and nutritive substances coming from the coastal zones bordering (ports, sea traffic, tourist complexes) and from the affluents, the Pomeranian Bay presents conditions of eutrophy of its water. The Germano-Polish Commission of frontier water carries out there since 1970, as in the lagoon of Szczecin, of measurements on the quality of water. These studies proceed April at November, on the levels of 4 measuring sites fixed by the German and Polish water Agencies (Fig 1). The results of these studies are published in the annual reports on the quality of water which is written in alternation by the German and Polish actors (STAUN 1993, PIOS 1994, STAUN 1995, PIOS 1996, STAUN 1997, PIOS 1998). 
The following data have been depouiled: salinity, nitrates, ammonium, orthophosphates, metals heavy, chlorophyl A and oxygen, for the period of 1992 to 1997, in Pomeranian Bay, at the measuring site nearest to the coast (station I) and at the station furthest away from the coast (station IV). The purpose of this evaluation is to judge the quality of water and their possible modifications during this period, compared with water of the lagoon of Szczecin. It will be advisable to analyze in same time the impact of believed of Oder, whose influence in the lagoon of Szczecin was shown, on the quality of water in Pomeranian Bay. The analyses of the rates taken at the measuring sites appear in Fig 2 to 4 and tables 4 and 5 .

Table 4 indicates that the rate of salinity is, in accordance with waitings, low at the station nearest to the coast (station I) that at the station furthest away from the coast. These lower rates can be explained by the fresh water surge coming from the lagoon of Szczecin.

Throught analyses of the taking away made in 1995 and 1997 (July-September) at station I appear it appears that the salt concentrations during july and sepyember 1997 are lower than those of the same period 1995, which apparently is a consequence of raw of Oder (PIOS 1996, PIOS 1998).

With regard to the content nitrates and the content ammonium, one notes no fall of the concentrations during several years (table 4). In general, the nitrate rates present in surface water vary; they are on average about $0,27 \mathrm{mg} / \mathrm{l}$ at station I and of $0,20 \mathrm{mg} / \mathrm{l}$ at station IV. The content higher nitrates noted than station $\mathrm{I}$ is due to the effluents charged in substances coming from the lagoon with Szczecin. In the annual reports, these variations are charged to the weather conditions, the growth of the phytoplankton as well as to flow and backward flow (STAUN 1997).

With regard to ammonium, one notes variations which give an average of env. $0,06 \mathrm{mg} / \mathrm{l}$ at station I and of env. $0,05 \mathrm{mg} / \mathrm{l}$ at station IV. August 25, 1997, the ammonium concentrations are assembled abruptly to the mouth of Swine (station I: $0,44 \mathrm{mg} / \mathrm{l}$ ), decreasing more one moved away from the coast (stationIII: $0,09 \mathrm{mg} / \mathrm{l}$, station IV: $0,00 \mathrm{mg} / \mathrm{l}$ ) (Fig 3). One can admit that this increase in the concentrations was started by the rising of Oder.

\section{Fig 3}

Ammonium concentration (in mg/l) in 1997 for stations I, III and IV in Bay of Poméranie (Source of the data: PIOS 1998)

The orthophosphate concentrations appearing in table 4 relate to the station nearest to the

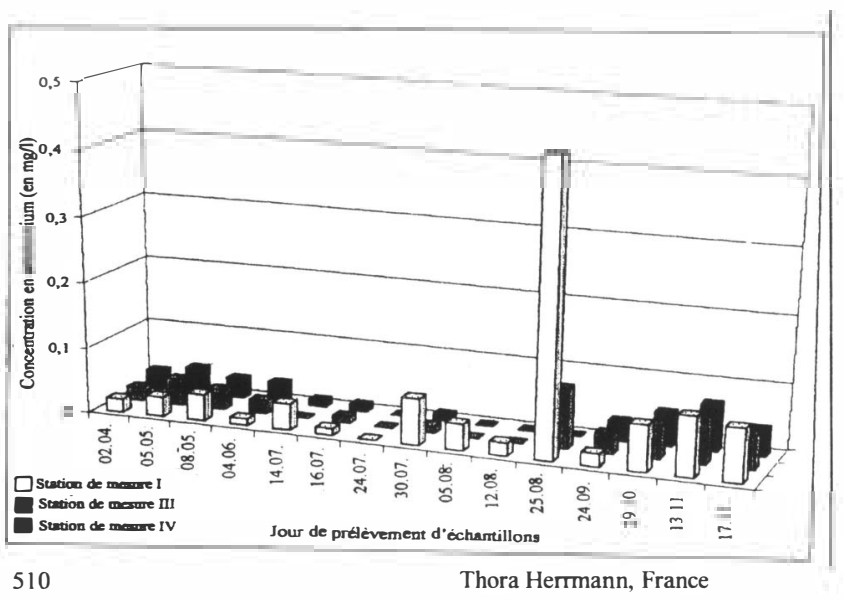


coast (station I) and that furthest away from the coast (station IV). As it was necessary to expect it, station I present of more raised rates, because of its proximity with the lagoon of Szczecin. If one compares the rates taken of 1992 to 1997, one notes a fall of the orthophosphate rates since 1992 at these two stations (station I: $1,5 \mu \mathrm{mol} / 1$ in 1992 and 0.97 $\mu \mathrm{mol} / \mathrm{l}$ in 1996; station IV: $1,284 \mu \mathrm{mol} / \mathrm{l}$ in 1992 and $0,61 \mu \mathrm{mol} / \mathrm{l}$ in 1996). In 1997 , the orthophosphate concentrations increased out of arrow on August 25, 1997. This increase was very marked at station I and it was decreasing the stations more was moved away and located towards the sea (Fig. 4). It is probable that the rising of Oder is also at the origin of this increase out of arrow of the concentrations which occurred on August 25, 1997 near the coasts.

\section{Fig 4}

Orthophosphate concentration (in mg/l) in 1997 for stations I, III and IV in Pomeranian Bay (Source of the data: PIOS 1998)

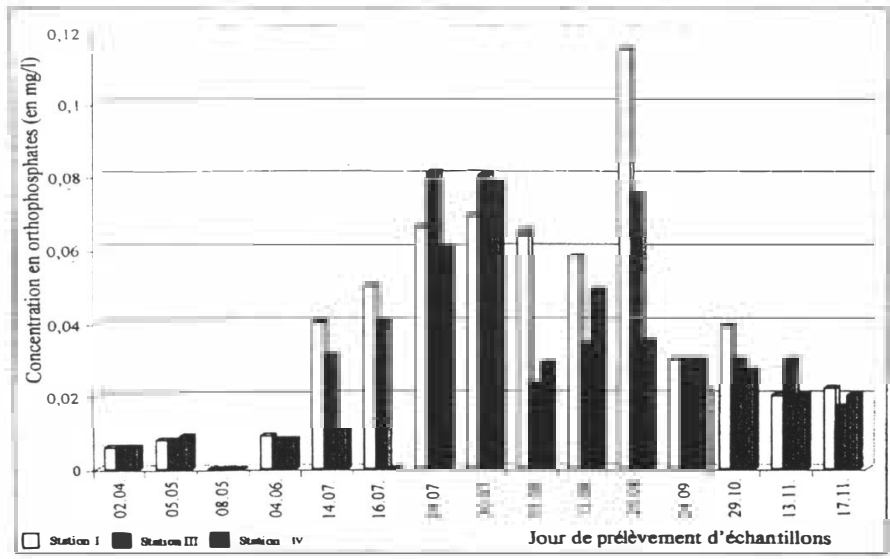

Measurements out of heavy metals were taken only at station IV. The zinc and lead, copper, mercury rates which were measured (tab 5) exceed the guideline figures fixed by the Commission of Helsinki (HELCOM); they are thus the proof of the pollution of Pomeranian Bay. It is necessary to seek of it the cause in the harbour activities, the sea traffic and the contribution of the rivers. The rising of Oder caused an increase in the lead concentrations in Pomeranian Bay which is even higher marked than in the lagoon of Szczecin. July 30, 1997, lead concentrations about $4,57 \mu \mathrm{g} / \mathrm{l}$ were recorded at station IV; they was highest since 1994 .

Table 4 indicates that the content chlorophyl $\mathbf{A}$ is higher at the station nearest to the coast that at the station furthest away from the coast, because of the contribution in nutritive substances coming from the lagoon of Szczecin. One notes at the two stations of the maximum seasonal rate which is due to a development of the phytoplankton in spring and in summer (STAUN 1993 - PIOS 1998, IOW 1997). The rising of Oder did not disturb the seasonal reproduction of algae (PIOS 1998).

In table 4 appear the oxygen contents measured in stations I and IV during the period of 1992 to 1997. The oxygen rates are decreasing, more one moves away from the coast. The concentrations oxygenates which are higher at the station station I indicate an increased 
biological contribution near the coast (higher contribution in nutritive substances by the lagoon of Szczecin, proliferation of the algae, higher oxygen concentration). In general, the oxygen concentrations tum between $8,4 \mathrm{mg} / \mathrm{l}$ and $10,9 \mathrm{mg} / \mathrm{l}$ (station I) and between $9 \mathrm{mg} / \mathrm{l}$ and $11,6 \mathrm{mg} / \mathrm{l}$ (station IV); these rates are lower than those of the lagoon of Szczecin already strongly eutrophied.

It is difficult to make an exact comparative analysis between the rates noted in the lagoon of Szczecin and those noted in Pomeranian Bay, since the samples were taken at different periods in the two water levels.

With regard to the rates of salinity, they show an increase, as one had to expect it, since the lagoon of Szczecin until the south of the Baltic. The rising of Oder reduced salinity to the full sea only for one short length of time. As regards the following nutritive substances (nitrates, ammonium and orthophosphates), one notes a significant fall since the estuary of Oder while passing by the lagoon of Szczecin towards north. The strongest degradation of the substances biologically dégradables takes place in the lagoon of Szczecin. The rates of the nitrate concentrations decrease since the estuary of Oder (station E: $1,12 \mathrm{mg} / \mathrm{l}$ in 1997) until the limits of the lagoon towards north (station b: $0,4 \mathrm{mg} / \mathrm{l}$ in 1997). In 1997, more rising rates that enters 0,16 to $0,1 \mathrm{mg} / \mathrm{l}$ were detected at the measuring sites I and IV in Pomeranian Bay. The lagoon of Szczecin is used as buffer zone and prevents that the marine pollution of the Baltic sea is not important any more. The importance thus proven of coastal water for the protection of water is explained only by the success of the bilateral cooperation in this frontier area.

The germano-Polish bilateral cooperation plays a particular part for the protection of the Baltic Sea, within the cooperation between bordering countries of the Baltic.

\section{Tab 4}

Annual averages of the parameters: salt, oxygen, nitrates, ammonium, orthophosphates, chlorophyl A in Pomeranian Bay at the 1992, measuring sites I and IV to 1997

(Source of the data: STAUN 1993, PIOS 1994, STAUN 1995, PIOS 1996, STAUN 1997, PIOS 1998)

\begin{tabular}{|c|c|c|c|c|c|c|}
\hline \multicolumn{7}{|c|}{ Measuring site I } \\
\hline Parameter & 1992 & 1993 & 1994 & 1995 & 1996 & 1997 \\
\hline Salt (\%) & 10,47 & 10,0 & 10,8 & 10,2 & 10,9 & 10,3 \\
\hline Oxygen (mg/l) & 6,37 & 6,37 & 6,05 & 5,45 & 5,0 & 5,0 \\
\hline Nitrates $(\mathrm{mg} / \mathrm{l})$ & 0,25 & 0,17 & 0,48 & 0,27 & 0,34 & 0,16 \\
\hline $\begin{array}{l}\text { Ammonium } \\
(\mathrm{mg} / \mathrm{l})\end{array}$ & 0,11 & 0,09 & 0,054 & 0,07 & 0,073 & 0,06 \\
\hline $\begin{array}{l}\text { Orthophos- } \\
\text { phates (mg/l) }\end{array}$ & 0,048 & 0,050 & 0,035 & 0,038 & 0,030 & 0,041 \\
\hline $\begin{array}{l}\text { Chlorophyl A } \\
\left(\mathrm{mg} / \mathrm{m}^{3}\right)\end{array}$ & 14,08 & 12,9 & 11,94 & 19,8 & 27,5 & 19,3 \\
\hline \multicolumn{7}{|c|}{ Measuring site IV } \\
\hline Parameter & 1992 & 1993 & 1994 & 1995 & 1996 & 1997 \\
\hline Salt (\%o) & 10,38 & 10,5 & 11,06 & 10,7 & 11,2 & 10,7 \\
\hline $\begin{array}{l}\text { Oxygen } \\
(\mathrm{mg} / \mathrm{l})\end{array}$ & 6,5 & 6,61 & 6,54 & 6,41 & 5,9 & 5,8 \\
\hline $\begin{array}{l}\text { Nitrates } \\
(\mathrm{mg} / \mathrm{l})\end{array}$ & 0,22 & 0,12 & 0,46 & 0,11 & 0,23 & 0,10 \\
\hline $\begin{array}{l}\text { Ammonium } \\
(\mathrm{mg} / \mathrm{l})\end{array}$ & 0,0635 & 0,11 & 0,05 & 0,04 & 0,05 & 0,02 \\
\hline $\begin{array}{l}\text { Orthophos- } \\
\text { phates (mg/l) }\end{array}$ & 0,039 & 0,045 & 0,026 & 0,027 & 0,019 & 0,026 \\
\hline $\begin{array}{l}\text { Chlorophyl A } \\
\left(\mathrm{mg} / \mathrm{m}^{3}\right)\end{array}$ & 15,73 & 10,3 & 10,65 & 12,6 & 14,3 & 16,4 \\
\hline
\end{tabular}


Tab 5 Annual averages of the heavy metal concentrations (in $\mu \mathrm{g} / \mathrm{l}$ ) for lead, copper, nickel, mercury and zinc in Poméranian Bay at the 1994, measuring site IV to 1997 (Source of the data: STAUN 1995, PIOS 1996, STAUN 1997, PIOS 1998)

\begin{tabular}{|l|l|l|l|l|l|}
\hline \multicolumn{9}{|c|}{ Measuring site IV } \\
\hline Metal heavy & $\mathbf{1 9 9 4}$ & $\mathbf{1 9 9 5}$ & $\mathbf{1 9 9 6}$ & $\mathbf{1 9 9 7}$ & $\begin{array}{l}\text { Directing rates indicated } \\
\text { by the HELCOM (ug/l) }\end{array}$ \\
\hline Lead $(\mu \mathrm{g} / \mathrm{l})$ & 0,47 & 0,17 & 1,25 & 1,073 & $0,05^{*}$ \\
\hline Copper $(\mu \mathrm{g} / \mathrm{l})$ & 2,47 & 2,03 & 6,0 & 1,35 & $0,05^{*}$ \\
\hline Nickel $(\mu \mathrm{g} / \mathrm{l})$ & 1,64 & 0,54 & 0,57 & 0,7 & $0,7-0,8$ \\
\hline Mercury $(\mu \mathrm{g} / \mathrm{l})$ & 0,07 & $<0,04$ & 0,04 & 0,028 & $0,003^{*}$ \\
\hline Zinc $(\mu \mathrm{g} / \mathrm{l})$ & 5,70 & 4,04 & 14,8 & 8,5 & $1-10$ \\
\hline
\end{tabular}

- The guideline figures apply to the coastal sections subjected to this influence, while all the other guideline figures relate to the central part of the Baltic

\section{Transborder german-polish cooperation within the framework of International Conventions on the protection of the Baltic Sea}

The close cooperation of the bordering countries of the Baltic within the framework of the " Helsinki Convention for the protection of the marine environment of the Baltic Sea " (March 22, 1974, renouvle in 1992) and of the Commission of Helsinki (HELCOM) produced some improvements of the state of the Baltic Sea, as it arises from the periodic reports (HELCOM 1979-1998). With regard to pollution with the phophates and nitrates, the studies of the sea waters Baltique which make the object of an international dialogue made it possible to show that in general, the changes intervening on the littoral appear only with one lag of 5 to 10 years in the central part of the Baltic sea(for example close to Bornholm).

The changes of the quality of water of the lagoon of Szczecin and the Pomeranian Bay which were exposed above have an impact in the shorter term: , [... the drastic reduction of the to fertilize consumption in the Baltic sea drainage area, which began in 1989/90, is not yet significantly reflected by decreasing nutrient winter concentrations. However, this does not apply the Arkona and Bornholm Sea where the first indifications are found that the averaged phosphate and nitrat concentrations are decreasing in winter. These obervations agree with the significantly decreasing nutrient load, for authority, in the Pomeranian Bight, southern Arkona Sea in recent times. " (HELCOM 1996, B). However, the lagoon of Szczecin/Pomeranian Bay form part of the 132 areas that the HELCOM defined as "Hot Spot" in term of raised pollution, and of which it claims the cleansing from here year 2013. In this context, the HELCOM instituted an action plan of the Baltic sea (Baltic Sea Joint Understanding Environmental Action Programs) which aimed at the development of plans of environmental management for 5 zones of project, of which also formed part the area of Oder. To this end, the special group of work (Areal Task Teams - ATT) Area of the lagoon of Oder was made up on July 1, 1994; it is composed of six Polish representatives and six German representatives.

Effiorts are made on the multinational level to protect the Baltic sea; in this respect, the transborder bilateral german-polish cooperation acquires a particular importance; it will be necessary to hold of it account during the attribution of financial assistances of the State. 


\section{Transborder management of ground water and the waste water in the frontier area Usedom-Est/Swinemünde (Swinoujscie)}

\section{Production of drinking water for the frontier area East-Usedom / Swinemünde (Swinoujscie)}

In the frontier area East- Usedom /Swinemünde (Swinoujscie) are the town of Swinemünde (Swinoujscie, 43375 inhabitants in 1996) on the Polish side and the seaside resorts Ahlbeck. Bansin, Heringsdorf (approx. 10000 inhabitants on the whole in 1996) on the German side. The drinking water consumption is tripled in summer because of the arrival of many holiday makers. The daily consumption rises in summer with approx. $2800 \mathrm{~m}^{3} / \mathrm{d}$ German side and approx. $8000 \mathrm{~m}^{3} / \mathrm{d}$ Polish side.

The East-Usedom /Swinemünde area forms a geological and hydrogeologic unit which is marked by small basins slopes, ground water low thickness and by a risk of salinisation, because of the presence of highly mineral-bearing water coming from subjacent chalky rocks (GLA 1999).

All water collectings [ German side: collecting with Ahlbeck-Zierowberg, AhlbeckJägersberg, Bansin-Forst Pudagla, Bansin-Neuhof, Gothen, Zirchow-Dorf, collecting envisaged with Zirchow; Polish side: Swinemünde-west, north (park), south ] exploit water starting from an aquifer which exceeds the zone concerned and is prolonged in all the directions to the Baltic).

It is estimated that from here year 2010, one will need 19500 underground water $\mathrm{m}^{3} / \mathrm{d}$ to ensure the drinking water supply of the german-polish frontier area East-Usedom /Swinemünde (Swinoujscie), these estimates base oneself on criteria of stock management out of water. that will represent $6800 \mathrm{~m}^{3} / \mathrm{d}$ on the German side and Polish side approx. $12700 \mathrm{~m}^{3} / \mathrm{d}$ (MUNDTHAL 1998).

In the national files of planning, the storing reservoir german-polish was declared as a problematic zone in the field of the drinking water, because of its requirements out of drinking water and its geological and hydrogeologic conditions. The supply drinking water presents difficulties, because of salted water invasion in principal the aquifers leading to fresh water (closing of the water collecting in Swinemünde-West in 1940), because of a saturation of the modest drinkable water a a resulte to important taking away and ecological damage. The increased exploitation of the drawing up of Swinemünde-West involved a significant fall of the water level in the lake Wolgastsee close to Heringsdorfi(depth of the lake in 1981/82: $83 \mathrm{~cm}$; in 1993: $47 \mathrm{~cm}$ ) (FREUDENBERG 1997). It will be possible to meet the requirements out of drinking water for all the area only if Germany and Poland make a common planning and adopt concerted measures of town planning.

Until 1996, the common activities were limited to the exchange of some hydrological data. The condotions of site made it possible that this area could be qualified like model - area for a project controls European, within the framework of the European Action Plan on underground water. October the 23, and 24 1997, the GUK (German-Polish Commission) created the German-Polish working group " transborder management of underground water of EastUsedom /Swinemünde ". In May 1998, a common plan of measurements was established for the management of resources water and hydrology. 
It constitutes the base of a concept to scientific base envisaging in the future the cover of the requirements of drinking water starting from the thin underground water resources.

In this respect, the following studies and projects are laid down: determination of the exploitable output of underground water, ecological repercussions of the exploitation of underground water, declaration of perimeters of drinking water protection, transborder management of underground water, monitoring system of undergroundwater (conservation of the evidence) and generalization of knowledge (GUK 1998).

This project planned for one 3 years duration must be financed by Community funds coming from Program INTERREG II (for the German part) and from the program PHARE (for the Polish part).

\section{Transborder treatment of the waste water in cooperation in the frontier area East- Usedom /Swinemünde (Swinoujscie)}

Because of the strong mitage of the studied zone, on the Polish side $42 \%$ only of the inhabitants of the area of the lagoon of Oder were connected in 1994 to a station of purification. while 57\% were it on the German side (HELCOM $1996 \mathrm{~A}$, c). the stations of purification located in the studied zone make for the majority only mechanical purification. Only $30 \%$ of the German stations of purification and $10 \%$ of the Polish stations of purification also have a biological phase of purification.

In this zone with the primarily rural character, the septic tanks are far from being always tight, which represents a danger to the ground water (UBA 1993, c). In summer, the situation is problematic especially in the seaside resorts. Two years ago still, the three seaside resorts Ahlbeck. Bansin and Heringsdorf did not have a station of purification. The waste water which had not been completely purified in the mud tank poured directly in the Baltic sea. In Swinemünde, the problems were similar. The station of purification which did not meet the technical standards any more insufficiently treated used water, which had negative repercussions for environment (NIEDZWIECKI and coll. 1998).

In order to improve quality of water of the coastal area, it was necessary to take concrete measures of water treatment used on a transborder scale. Within the framework of these activities. a project controls environmental protection was decided in 1991. It is entitled: " German-Polish Station of purification of Swinemünde " (URZAD MIEJSKIEGO 1997). In 1993. the treaty was signed between Zweckverband Wasserversorgung und Abwasserbeseitigung Insel Usedom (administrative Unit of the water supply and the drainage of waste water of the Usedom island) and the town of Swinemünde; it includes the following projects: construction of a station of purification with a construction of clarification sludge discharge in Swinemünde, of a directing system of collection and an automatic mine pump on the Polish and German side, construction of a pressure line of waste water on the German side to the border (Fig 5). 


\section{Fige 5}

The station of purification of Swinemünde

(Source: URZAD MIEJSKIEGO W Swinoujscie 1997)

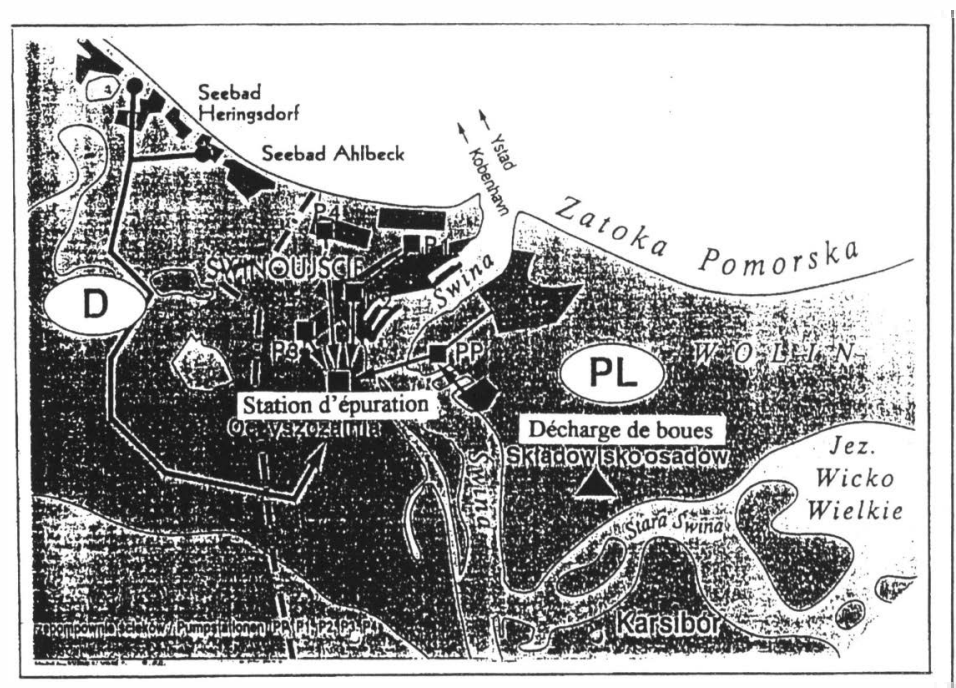

The station of common purification was put in exploitation in February 1997; of mécanicobiological type, it is possible to equip it with a chemical secondary decantation, in order to degrade the phosphorated compounds. The transformation while electrical current of the biogas formed by the degradation of digested muds contributes to climatic protection.

The new station of purification of Swinemünde is an important factor of improvement of the quality of water of the mouth of Swine and Pomeranian Bay. The station of purification must make it possible to reduce the marine pollution Baltique of approximately $5400 \mathrm{~T}$ of organic carbonaceous compounds, of $400 \mathrm{~T}$ nitrogen and $120 \mathrm{~T}$ phosphorus. Envisaged to serve 185 000 inhabitants, the station will be able in the future also to evacuate the increased volume of waste water resulting from the rise of tourism.

\section{$\underline{\text { Discussion and Conclusion }}$}

The German-Polish cooperation as regards environmental protection goes already back to the years of post-war period, in particular with regard to the stock management out of water. Following the political changes occurred in the countries of the old Eastern bloc in 1989/90, it is a new quality of the cooperation which is ambitionned. Many transborder activities were launched in the sector of the environment. Another track which was followed are the assistances granted by the European Union for specific sectors. The objective must consist in coordinating work of the various committees, unions, companies and commissions to thus reinforce the effectiveness of measurements applied. It is imperative to avoid double employment, in order to judiciously use financial means which is limited. 
Using specific examples, this paper tried to expose the recorded successes in this framework and the progress resulting for the environment. The developments in the field of the drainage worn are very positive on the East-Usedom/Swinemünde site. With regard to the coordination of the drinking water supply, a dialogue on a whole series of points is apparently still necessary.

In the field of the cooperation in the field of the protection of water The analysis of the state of running waters has proximity of the border should be one of the paramount missions. It would be advisable to work out a program common and coordinated to review state of the frontier rivers (evaluation of the studies in series relating to the loads in harmful substances of Oder until the Baltic sea, studies of bearing site on the type and the quantity of the nutritive matters). Moreover it would be necessary to work out a common plan of protection of water and a concept of re-establishment of the natural mode of water and of renaturation of the easily flooded zones. A close cooperation with institutions of research and associations of nature conservancy is desirable.

Generally, it is possible to affirm that the frontier area of the estuary of Oder is in good way to become a Euroregion. It is more necessary than ever to have comparative data with frontier areas already created in Europe, in order to benefit from the positive experiments and suggestions which were made and thus to prevent in time of the errors.

\section{$\underline{\text { References }}$}

- BLUM 1997 B: Ministerium für Bau, Landesentwicklung und Umwelt (BLUM) (Ed.) 1997: Der Umwelthericht 1997, Schwerin, p.68

- FREUDENBERG.K. Umwelt Plan GmbH Stralsund 1997: Studie: Wasserbewirtschaftung fiir die Trinkw'sserversorgung der Region Ost-Usedom/Swinemünde, Stralsund, p. 16

- GLA 1999: Geologisches Landesamt (GLA) 1999: Der Geologische Dienst, Mecklenhurg-Vorpommern: 8.Jahre Partner von Behörden und Wirtschaft für geowissenschaftliche Fragenstellungen, Schwerin, p. 36-37

GUK 1998: Gemeinsame Umweltkommission Mecklenburg-Vorpommern/ Wojewodschaft Stettin (GUK) 1998: wasserwirtschafilicher und hydrogeologischer Maßnahme plan zur Erarbeitung einer grenzüberschreitenden Grundwassrebewirtschafiungskonze ption zur Schicherung der Trinkwasserversorgung des deutsch-polnischen Versorgungsgebietes Ost-Usedom, 13 p.

GWK 1999: Deutsch-Polnische Grenzgewässerkomission Arbeitsgruppe W2 „Grewässerschutz" Polsko-Niemiecka Konisja do spraw wod granicznych Grupa robocza W-2 „Ochrona Wod“( (Ed.), 1999: Untersuchung und Einschätzung der Wasserbeschaffenheit der Grenzgewässser im Jahr 1998 -Badania i ocena jakooeci polsko-niemieckich wod granicznych w 1998 roku, Teil I Czeoeae I, Zinnowitz/Usedom 1999

- HELCOM 1979-1998: Helsinki Kommission (HELCOM) - Baltic marine Environment Protection Commission Helsinki Kommission (HELCOM) Baltic sea Environment Proceedings, Nr 1 (1979) - Nr.75 (1998) HELCOM 1996 A: Helsinki Kommission (HELCOM) -Odra Lagoon Area Task Team1996: Integreated Coastel Zone Management Plan (ICZMP), Greifswald-Szczecin, p. 64 
- HELCOM 1996 B: Helsinki Commission (HELCOM) (Ed.) 1996: Third Assessment of the state of the marine Environment of ithe Baltic Sea 1989-93, Background Document in Baltc Sea Environment Proceedings, No: 64 B, p. 103

- HELCOM 1998: Helsinki Kommission (HELCOM) (Ed.) 1998: Red List of marine amd coastel biotopes and biotop complexes of the Baltic Sea and Kattegat, Baltic Sea Environment Proceedings, Nr. 75, 1998

- IOW 1997: Institut für Ostseeforschung Warnemünde (IOW) an der Universität Rostock, (Ed.) 1997: A ufhaubericht 1992-1996, Rostock, p. 107

- MUNDTHAL,H. 1998: „Aufgaben und Ziele der projektbezogenen deutsch-polnischen Arbeitsgruppe grenzüberschreitende Grundwasserbewirtschaftung OstUsedom/Swinemünde“, In: STAUN Ueckermünde (Ed.), 1998: Informationsveranstaltung im Rahmen der Europa-Wochei,, Trinkwasserversorgung (Ost-Usedom/'Swinemünde) “, 06.06.1998, p.9-10

- NIEDZWIECKI,E.; PROTASOWICKI,M.; CZYZ,H.; SLIWINKSI,D.; NOWAK,Z. 1998: „Wykorzystanie osadow z oczyszczalni sciekow komunalnych w Swinoujscie do rekultywacji terenow piaszczystych“, in: Staowrzyszenie inzynierowi technikow przemyslu chemicznego Szczecin (Poland), Kommission Reinhaltung der Luft (KRdL) im VDI und DIN Düsseldorf (Germany), Instytut techniki cieplny politechniki warszawskiej, Warszawa. 6-th International symposium "Integreated Approach to pollution prevention and to avoidance minimization and disposal of iwaste, 05.-07.05.1998 in Szczecin Poland, p. 151-157

- PIOS 1993 : PANSTWOW A INSPEKCJA OCHRONY SRODOWISKA (PIOS) Wojewodski inspektorat Ochrony srodowiska w Szczecine, 1993i Zalew SzczecinskiiStettiner Haff: Sprawozdanie z badan polsko-niemieckich badan wykonanych w 1992 roku. Szczecin, $24 \mathrm{p}$.

- PIOS 1994: PANSTWOWA INSPEKCJA OCHRONY SRODOWISKA (PIOS) Wojewodski inspektorat Ochrony srodowiska w Szczecine, 1994: Zatoka PomorskaiOderbucht: Sprawozdanie z polsko-niemieckich badan wykonanych w 1993 roku, Szczecin. 26 p.

PIOS 1995 PANSTWOWA INSPEKCJA OCHRONY SRODOWISKA (PIOS) Wojewodski inspektorat Ochrony srodowiska w Szczecine, 1995: Zalew Szczecinski Stettiner Haff: Sprawozdanie z badan polsko-niemieckich badan wykonanych w 1994 roku. Szczecin

- PIOS 1996: PANSTWOWA INSPEKCJA OCHRONY SRODOWISKA (PIOS) Wojewodski inspektorat Ochrony srodowiska w Szczecine, 1996: Zatoka PomorskaiOderbucht: Sprawozdanie z polsko-niemieckich badan wykonanych w 1995 roku, Szczecin, $28 \mathrm{p}$.

- PIOS 1997: PANSTWOWA INSPEKCJA OCHRONY SRODOWISKA (PIOS) Wojewodski inspektorat Ochrony srodowiska w Szczecine, 1997: Zalew Szczecinski Stettiner Haff: Sprawozdanie z badan polsko-niemieckich badan wykonanych w 1996 roku, $17 \mathrm{p}$.

PIOS 1998: PANSTWOWA INSPEKCJA OCHRONY SRODOWISKA (PIOS) Wojewodski inspektorat Ochrony srodowiska w Szczecine, 1998: Zatoka Pomorska -Pommersche Bucht: Sprawozdanie z polsko-niemieckich badan wykonanych w 1997 roku, Szczecin, $25 \mathrm{p}$.

PIOS 1999: PANSTWOWA INSPEKCJA OCHRONY SRODOWISKA (PIOS) Wojewodski inspektorat Ochrony srodowiska w Szczecine, 1999: Zalew SzczecinskiStettiner Haff: Sprawozdanie z badan polsko-niemieckich badan wykonanych w 1998 roku, Szczecin, $26 \mathrm{p}$. 
- STAUN 1993: Staatliches Amt für Umwelt und Natur (STAUN) Stralsund, Dezernat 330 - Gewässerüberwachung / Labor, 1993: Jahresbericht 1992 zur Wassergüte des Grenzgewässers Oderbucht - Zatoka Pomorska, Stralsund, 29 p.

- STAUN 1994: Staatliches Amt für Umwelt und Natur (STAUN) Stralsundi, 1994: Oderhaff-Zalew Szczecinski, Gütezustand des Grenzgewässers 1993, Stralsund

- STAUN 1995: Staatliches Amt für Umwelt und Natur (STAUN) Stralsundi, 1995: Pommersche Bucht-Zatoka Pomorska, Gütezustand des Grenzgewässers 1994, Stralsund

- STAUN 1996: Staatliches Amt für Umwelt und Natur (STAUN) Stralsund, 1996: Stettiner Haff-Zalew Szczecinski, Gütezustand des Grenzgewässers 1995, Stralsund STAUN 1997: Staatliches Amt für Umwelt und Natur (STAUN) Stralsundi, 1997: Pommersche Bucht-Zatoka Pomorska, Gütezustand des Grenzgewässers 1996, Stralsund

- STAUN 1998: Staatliches Amt für Umwelt und Natur (STAUN) Stralsundi, 1998: Stettiner Hauff-Zalew Szczecinski, Gütezustand des Grenzgewässers 1997, Stralsund

- UM 1992: Umweltministerium des Landes Mecklenburg-Vorpopmmern (UM) 1992: Oderhaff-Zalew Szczecinski, Gütezustand des Grenzgewässers 1991, Schwerin

- URZAD MIEJSKIEGO w Swinoujscie 1997: Polsko-niemiecki pilotazowy projekt w dziedzinie ochrony srodowiskal Deutsch-Polnisches Umweltplilotprojekt: Oczyszczalnia Swinoujscie/ Kläranlage Swinemünde, Szczecin, 1997 